\title{
PENERAPAN METODE PERAMALAN SEBAGAI ALAT BANTU UNTUK MENENTUKAN PERENCANAAN PRODUKSI DI PT. SKK
}

\author{
Widhy Wahyani, Achmad Syaichu \\ Jurusan Teknik Industri STT POMOSDA Nganjuk, Jawa Timur \\ syaichu07@gmail.com
}

\begin{abstract}
ABSTRAK
Pada PT. SKK., bahan baku yang ada sering kali tidak bisa mendukung kelancaran proses produksi, tenaga kerja dan fasilitas produksi yang ada tidak sesuai dengan yang dibutuhkan. Begitu juga dengan kapasitas produksi, output yang dihasilkan tidak bisa memenuhi permintaan supplier yang bersifat naik turun (fluktuatif). Akibatnya, produktivitas perusahaan menurun karena banyaknya permintaan (order) yang ditolak oleh perusahaan. Maka tujuan diakannya penelitian ini adalah mengestimasikan (meramalkan) permintaan pasar dimana bisa dijadikan dasar untuk membuat suatu perencanaan produksi, dengan menentukan berapa jumlah produk yang akan dihasilkan, kapan dan berapa jumlah bahan baku yang harus disediakan untuk mendukung kelancaran proses produksi, mendayagunakan sumberdaya yang terbatas secara efektif, dan meningkatkan kapasitas produksi guna memenuhi naik turunnya (fluktuatif) permintaan, sehingga produktivitas perusahaan dapat ditingkatkan. Setelah dilakukan peramalan melalui bantuan perangkat lunak Software QM for Windows khususnya untuk Metode Regresi Linier diperoleh nilai yang lebih kecil, dimana untuk masing - masing itemnya adalah sebagai berikut: untuk $M A D=8.812$, MSE $=146.237 .392$, Bias $=0$, untuk periode berikutnya diramalkan permintaannya sebesar 63.291,6 unit. Sedangkan jika menggunakan metode Exponential Smoothing diperoleh nilai-nilai sebagai berikut: untuk MAD $=13.374,1484$, MSE = 235.115.376, Bias = -549,8485, untuk periode berikutnya diramalkan jumlah permintaannya adalah sebesar 54.922,2266 unit. Sebagaimana diketahui bahwa nilai dari Metode Regresi Linier lebih kecil dibandingkan dengan metode Exponential Smoothing yang memiliki nilai ukuran akurasi kesalahan yang lebih kecil baik secara manual maupun dengan menggunakan software QM for Windows.
\end{abstract}

Kata kunci : perencanaan produksi, peramalan, QM for Windows, Exponential Smoothing, Regresi Linier

\section{PENDAHULUAN}

Perkembangan dunia industri dalam beberapa tahun belakangan ini semakin pesat, hal ini merupakan akibat dari adanya kebutuhan atau tuntutan dari konsumen yang semakin kompleks. Untuk memenuhi tuntutan tersebut, pihak produsen dalam hal ini perusahaan harus mampu meningkatkan efektifitas dan efisiensi kerja, sebab jika tidak maka perusahaan tidak akan mampu bersaing dengan perusahaan lainnya bahkan bisa tertinggal [1].

PT. SKK adalah sebuah perusahaan yang bergerak di bidang penyedia produk-produk manufaktur brighteners optik, pewarna dan tinta flexographic. Dalam memenuhi permintaan dari berbagai perusahaan yang membutuhkan produk yang dihasilkan tersebut, PT. SKK membuka cabang di berbagai tempat yang dekat dengan supplier agar dapat menghemat biaya transportasi. Seperti halnya pada PT. SKK cabang Sidoarjo. Dalam menjalankan rencana produksinya perusahaan ini masih menggunakan perencanaan produksi yang dibuat secara sederhana dan hanya berdasarkan pengalaman produksi yang pernah ada saja tanpa adanya setuhan-sentuhan manajemen yang up to date (terbaru). Akibatnya perusahaan belum bisa mengetahui rencana produksi yang diterapkan sudah berjalan optimal ataukah belum.

Bahan baku yang ada sering kali tidak bisa mendukung kelancaran proses produksi, tenaga kerja dan fasilitas produksi yang ada tidak sesuai dengan yang dibutuhkan. Begitu 
juga dengan kapasitas produksi, output yang dihasilkan tidak bisa memenuhi permintaan supplier yang bersifat naik turun (fluktuatif) [2]. Akibatnya, produktivitas perusahaan akan menurun karena banyaknya permintaan (order) yang ditolak oleh perusahaan. Maka dari itu, dari penelitian ini akan dibuat suatu perencanaan produksi yang bertujuan untuk menentukan berapa jumlah produk yang akan dihasilkan, kapan dan berapa jumlah bahan baku yang harus disediakan untuk mendukung kelancaran proses produksi, mendayagunakan sumberdaya yang terbatas secara efektif, dan meningkatkan kapasitas produksi guna memenuhi naik turunnya (fluktuatif) permintaan, sehingga produktivitas perusahaan dapat ditingkatkan.

\section{METODOLOGI PENELITIAN}

Untuk mengetahui permasalahan yang diperlukan, perlu adanya suatu pendekatan yaitu dengan langkah-langkah untuk mendapatkan data yang dibutuhkan dan berkaitan dengan masalah yang sedang diteliti. Adapun langkah-langkah dalam penulisan ini adalah sebagai berikut :

a. Survey dan Observasi lapangan

Dengan melakukan pengamatan secara langsung pada perusahaan dan meminta keterangan terhadap pihak yang terkait di lapangan, sehingga nantinya data yang diperoleh lebih akurat.

b. Wawancara dan Diskusi

Melakukan pengumpulan data dengan melalui tanya jawab dan diskusi secara langsung terhadap pihak yang terkait.

c. Studi Kepustakaan

Dengan melakukan pencatatan data-data atau dokumen yang diperlukan pada PT. SKK cabang Sidoarjo.

\section{HASIL DAN PEMBAHASAN}

\section{A. Pengumpulan Data}

Dari hasil pengamatan yang telah dilakukan terhadap permintaan seluruh jenis tinta yang diproduksi di PT. SKK cabang Sidoarjo, maka diperoleh permintaan sebagai berikut pada tabel 1 .

Tabel 1. Data Permintaan Tinta PT. SKK cabang Sidoarjo (Sumber: PT. SKK).

\begin{tabular}{|c|l|c|}
\hline Periode & \multicolumn{1}{|c|}{ Bulan } & Jumlah Permintaan (kg) \\
\hline \multirow{7}{*}{2013} & Januari & 59.376 \\
\cline { 2 - 3 } & Februari & 54.507 \\
\cline { 2 - 3 } & Maret & 39.661 \\
\cline { 2 - 3 } & April & 62.898 \\
\cline { 2 - 3 } & Mei & 73.257 \\
\cline { 2 - 3 } & Juni & 80.903 \\
\cline { 2 - 3 } & Juli & 57.616 \\
\cline { 2 - 3 } & Agustus & 54.249 \\
\cline { 2 - 3 } & September & 62.450 \\
\cline { 2 - 3 } & Oktober & 54.170 \\
\hline Jumlah & & 599.087 \\
\hline
\end{tabular}

\section{B. Pengolahan Data}

Dari data permintaan tinta tersebut, maka dapat dilakukan suatu peramalan untuk permintaan tinta PT. SKK cabang Sidoarjo pada periode selanjutnya. Untuk menghitug peramalan tersebut, kita menggunakan metode Exponential Smoothing dan metode Regresi Linier. Dari kedua metode tersebut, kami memilih metode yang lebih akurat dari hasil peramalannya. 
Dari grafik permintaan tinta tersebut menunjukkan bahwa tingkat permintaan selama tahun 2013 terendah terjadi pada bulan Maret sebesar $39.661 \mathrm{~kg}$, sedangkan tertinggi terjadi pada bulan Juni dengan jumlah permintaan sebesar $80.903 \mathrm{~kg}$.

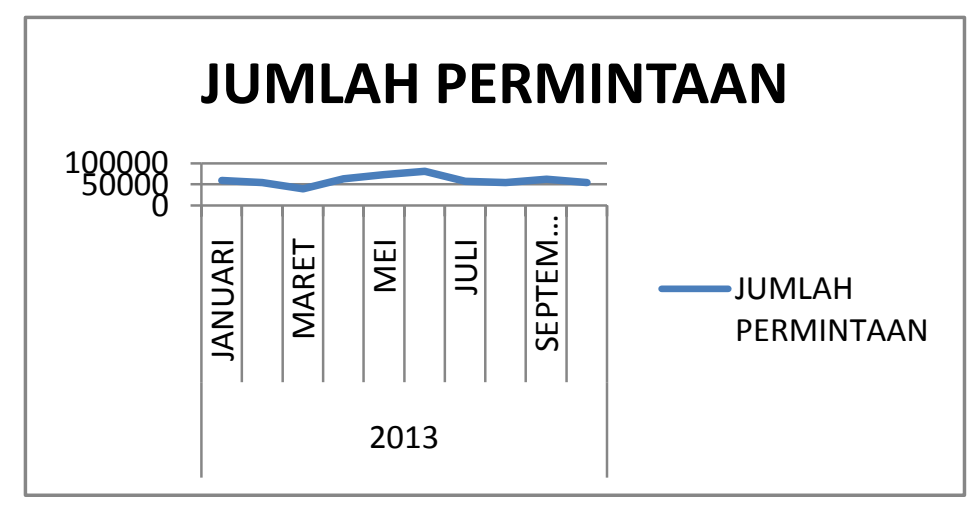

Gambar 1. Grafik Permintaan Aktual (Sumber: PT. SKK).

\section{Perhitungan dengan Metode Peramalan}

Untuk menghitung peramalan jumlah permintaan tinta PT. SKK cabang Sidoarjo tersebut, kita menggunakan metode Exponential Smoothing dan Regresi Linier. Dengan asumsi permintaan dilakukan sebanyak 1 (satu) bulan ke depan dan dari kedua metode tersebut, kami memilih metode yang lebih akurat hasil peramalannya.

\section{Exponential Smoothing (ES)}

Perhitungan Manual

Kita akan menggunakan model pemulusan metode ini untuk meramalkan permintaan produksi kertas kita menggunakan $\alpha=0,9$ ini dikarenakan data yang sangat bergejolak atau berfluktuasi dari waktu ke waktu, kita akan menggunakan nilai konstanta pemulusan yang cukup tinggi, mendekati nilai satu. Perhitungan berdasarkan $E S(\alpha=0,9)$.

Tabel 2. Hasil Peramalan Dengan Exponential Smoothing (ES).

\begin{tabular}{|l|c|c|c|}
\hline \multicolumn{1}{|c|}{ Bulan } & $\begin{array}{c}\text { Indeks } \\
\text { Waktu } \\
(\mathrm{t})\end{array}$ & $\begin{array}{c}\text { Permintaan } \\
\text { Aktual } \\
(\mathrm{A})\end{array}$ & $\begin{array}{c}\text { Ramalan Berdasarkan } \\
\text { ES }(\alpha=0,9) \\
(\mathrm{Ft} E S \alpha=0,9)\end{array}$ \\
\hline Januari & 1 & 59.376 & 59.376 \\
\hline Februari & 2 & 54.507 & $59.376+0,9(59.376-59.376)=59.376$ \\
\hline Maret & 3 & 39.661 & $59.376+0,9(54.507-59.376)=54.994$ \\
\hline April & 4 & 62.898 & $54.994+0,9(39.661-54.507)=41.633$ \\
\hline Mei & 5 & 73.257 & $41.633+0,9(62.898-39.661)=62.546$ \\
\hline Juni & 6 & 80.903 & $62.546+0,9(73.257-62.898)=71.869$ \\
\hline Juli & 7 & 57.616 & $71.869+0,9(80.903-73.257)=78.750$ \\
\hline Agustus & 8 & 54.249 & $78.750+0,9(57.616-80.903)=57.792$ \\
\hline September & 9 & 62.450 & $57.792+0,9(54.249-57.616)=54.762$ \\
\hline Oktober & 10 & 54.170 & $54.762+0,9(62.450-54.249)=62.143$ \\
\hline Nopember & 11 & 59.434 & $62.143+0,9(54.170-62.450)=54.691$ \\
\hline \multicolumn{1}{|c|}{ Jumlah } & & & 657.932 \\
\hline
\end{tabular}

Angka peramalan pada bulan November diperoleh dari: 653.778/11 $=59.434$ $\mathrm{kg}$ dan seterusnya, dimasukkan ke dalam perhitungan ukuran akurasi hasil peramalan. 
Tabel 3. Perhitungan Ukuran Akurasi Hasil Peramalan Dengan Exponential Smoothing (ES).

\begin{tabular}{|c|c|c|c|c|c|}
\hline $\begin{array}{c}\text { Indeks } \\
\text { Waktu } \\
(\mathrm{t})\end{array}$ & $\begin{array}{c}\text { Permintaan } \\
\text { Aktual } \\
(\mathrm{A})\end{array}$ & $\begin{array}{c}\text { Ramalan } \\
(\mathrm{F})\end{array}$ & $\begin{array}{c}\text { Deviasi } \\
\mathrm{A}-\mathrm{F}\end{array}$ & $\begin{array}{c}\text { Deviasi } \\
\text { Absolut } \\
\mathrm{I}-\mathrm{F} \mid\end{array}$ & $\begin{array}{c}\text { Kuadrat } \\
\text { Kesalahan } \\
(A-F)^{2}\end{array}$ \\
\hline 1 & 59.376 & 59.376 & 0 & 0 & 0 \\
\hline 2 & 54.507 & 59.376 & -4.869 & 4.869 & 23.707 .161 \\
\hline 3 & 39.661 & 54.994 & -15.333 & 15.333 & 235.100 .889 \\
\hline 4 & 62.898 & 41.633 & 21.265 & 21.265 & 452.200 .225 \\
\hline 5 & 73.257 & 62.546 & 10.711 & 10.711 & 114.725 .521 \\
\hline 6 & 80.903 & 71.869 & 9.034 & 9.034 & 81.613 .156 \\
\hline 7 & 57.616 & 78.750 & -21.134 & 21.134 & 446.645 .956 \\
\hline 8 & 54.249 & 57.792 & -3.543 & 3.543 & 12.552 .849 \\
\hline 9 & 62.450 & 54.762 & 7.688 & 7.688 & 59.105 .344 \\
\hline 10 & 54.170 & 62.143 & -7.973 & 7.973 & 63.568 .729 \\
\hline 11 & 59.434 & 54.691 & 4.743 & 4.743 & 22.496 .049 \\
\hline Jumlah & & 657.932 & 589 & 106.293 & 1.511 .715 .879 \\
\hline
\end{tabular}

$$
\begin{aligned}
& \text { MAD }=\sum\left|\frac{A-F}{n}\right|=\frac{106.293}{11}=9.663,00 \\
& \text { MSE }=\sum \frac{(A-F)^{2}}{n}=\frac{1.511 .715 .879}{11}=137.428 .716,27 \\
& \text { MFE }=\sum \frac{A-F}{n}=\frac{589}{11}=53,55
\end{aligned}
$$

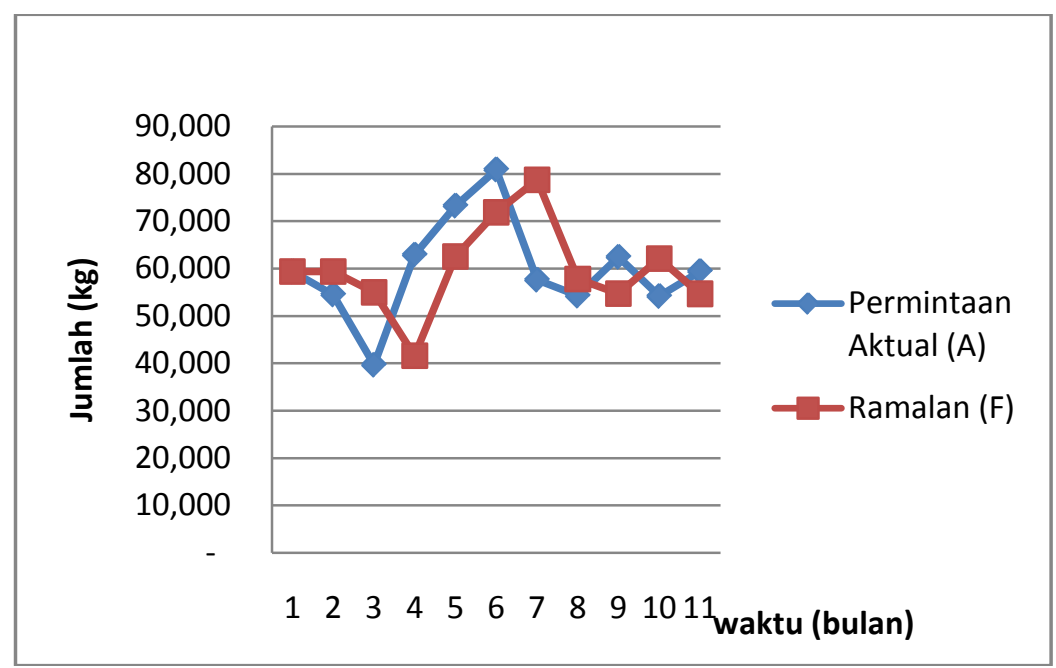

Gambar 2. Grafik Permintaan Aktual dan Peramalan Exponential Smoothing.

\section{Software QM}

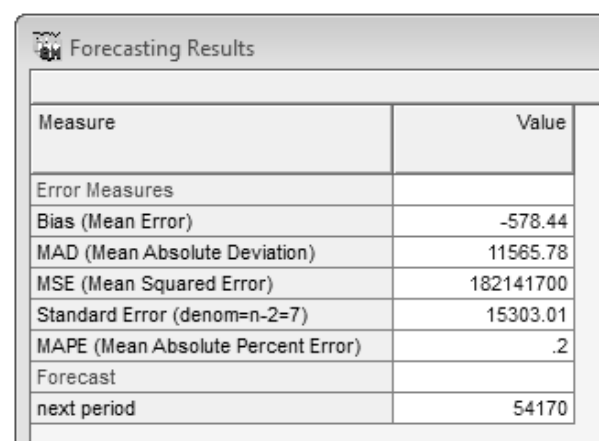

Gambar 3. Hasil Peramalan Exponential Smoothing. 


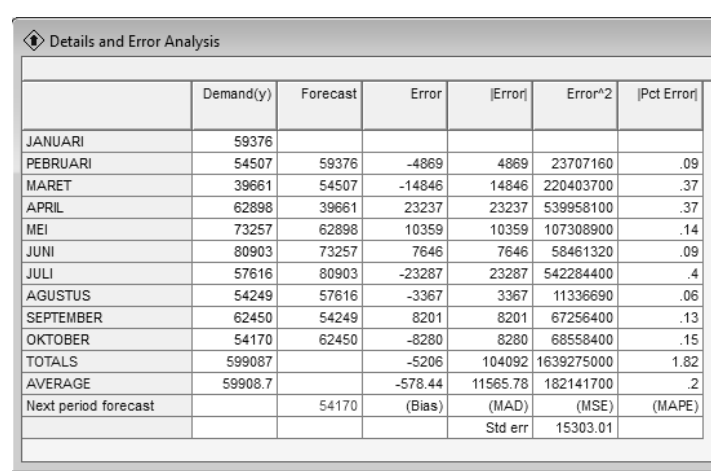

Gambar 4. Rincian dan Analisa Kesalahan Peramalan Exponential Smoothing.

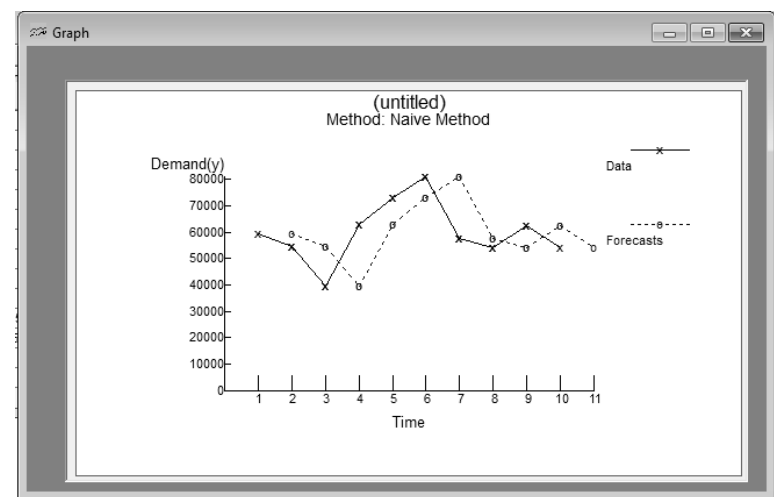

Gambar 5. Grafik Peramalan Exponential Smoothing

\section{Regresi Linier \\ Perhitungan Manual}

Tabel 4. Perhitungan Awal Sebelum Peramalan Dengan Regresi Linier.

\begin{tabular}{|l|c|c|c|c|}
\hline $\begin{array}{c}\text { Bulan } \\
\text { (Tahun 2013) }\end{array}$ & $\begin{array}{c}\text { Indeks Waktu } \\
(\mathrm{x})\end{array}$ & $\begin{array}{c}\text { Permintaan Aktual } \\
(\mathrm{y})\end{array}$ & $x^{2}$ & x.y \\
\hline Januari & 1 & 59.376 & 1 & 59.376 \\
\hline Februari & 2 & 54.507 & 4 & 109.014 \\
\hline Maret & 3 & 39.661 & 9 & 118.983 \\
\hline April & 4 & 62.898 & 16 & 251.592 \\
\hline Mei & 5 & 73.257 & 25 & 366.285 \\
\hline Juni & 6 & 80.903 & 36 & 485.418 \\
\hline Juli & 7 & 57.616 & 49 & 403.312 \\
\hline Agustus & 8 & 54.249 & 64 & 433.992 \\
\hline September & 9 & 62.450 & 81 & 562.050 \\
\hline Oktober & 10 & 54.170 & 100 & 541.700 \\
\hline \multicolumn{1}{|c|}{ Jumlah } & 55 & 599.087 & 385 & 3.331 .722 \\
\hline
\end{tabular}

$$
\mathrm{b} \quad \begin{aligned}
= & \frac{\left(n \cdot \sum x y\right)-\left(\sum x \cdot \sum y\right)}{\left(n \cdot \sum x^{2}\right)-\left(\sum x\right)^{2}} \\
& =\frac{(10 \cdot 3.331 .722)(55 \cdot 599.087)}{(10 \cdot 385)(55)^{2}}=445,38 \\
\mathrm{a} & =\frac{\sum y}{n}-b \frac{\sum x}{n} \\
& =\frac{599.087}{10}-445,38 \frac{55}{10}=57.459,13
\end{aligned}
$$

Jadi:

$\hat{\mathrm{y}}=\mathrm{a}+\mathrm{bx}$

$\hat{y}=57.459,13+445,38 x$

Maka:

Tabel 5. Hasil Peramalan Dengan Regresi Linier.

\begin{tabular}{|l|c|c|c|}
\hline $\begin{array}{c}\text { Bulan } \\
\text { (Tahun 2013) }\end{array}$ & $\begin{array}{c}\text { Indeks Waktu } \\
(\mathrm{x})\end{array}$ & $\begin{array}{c}\text { Permintaan Aktual } \\
(\mathrm{y})\end{array}$ & $\begin{array}{c}\text { Peramalan } \\
(\mathrm{F})\end{array}$ \\
\hline Januari & 1 & 59.376 & $57.904,51$ \\
\hline Februari & 2 & 54.507 & $58.349,89$ \\
\hline Maret & 3 & 39.661 & $58.795,27$ \\
\hline April & 4 & 62.898 & $59.240,65$ \\
\hline Mei & 5 & 73.257 & $59.686,03$ \\
\hline
\end{tabular}




\begin{tabular}{|l|c|c|c|}
\hline Juni & 6 & 80.903 & $60.131,41$ \\
\hline Juli & 7 & 57.616 & $60.576,79$ \\
\hline Agustus & 8 & 54.249 & $61.022,17$ \\
\hline September & 9 & 62.450 & $61.467,55$ \\
\hline Oktober & 10 & 54.170 & $61.912,93$ \\
\hline \multicolumn{1}{|c|}{ Jumlah } & 55 & 599.087 & $661.445,51$ \\
\hline
\end{tabular}

Untuk permintaan pada periode selanjutnya (November 2013) yaitu:

$$
\begin{aligned}
\hat{y} & =57.459,13+445,38 x \\
& =57.459,13+445,38(11)=62.358,51
\end{aligned}
$$

Dimasukkan ke dalam perhitungan ukuran akurasi hasil peramalan.

Tabel 6. Perhitungan Ukuran Akurasi Hasil Peramalan Dengan Regresi Linier.

\begin{tabular}{|c|c|c|c|c|c|}
\hline $\begin{array}{c}\text { Indeks } \\
\text { Waktu } \\
\text { (t) (x) }\end{array}$ & $\begin{array}{c}\text { Permintaan } \\
\text { Aktual } \\
(\mathrm{A})(\mathrm{y})\end{array}$ & $\begin{array}{c}\text { Ramalan } \\
(\mathrm{F})\end{array}$ & $\begin{array}{c}\text { Deviasi } \\
\mathrm{A}-\mathrm{F}\end{array}$ & $\begin{array}{c}\text { Deviasi } \\
\text { Absolut } \\
\text { | A - F }\end{array}$ & $\begin{array}{c}\text { Kuadrat Kesalahan } \\
(A-F)^{2}\end{array}$ \\
\hline 1 & 59.376 & $57.904,51$ & $1.471,49$ & $1.471,49$ & $2.165 .282,82$ \\
\hline 2 & 54.507 & $58.349,89$ & $-3.842,89$ & $3.842,89$ & $14.767 .803,55$ \\
\hline 3 & 39.661 & $58.795,27$ & $-19.134,27$ & $19.134,27$ & $366.120 .288,43$ \\
\hline 4 & 62.898 & $59.240,65$ & $3.657,35$ & $3.657,35$ & $13.376 .209,02$ \\
\hline 5 & 73.257 & $59.686,03$ & $13.570,97$ & $13.570,97$ & $184.171 .226,74$ \\
\hline 6 & 80.903 & $60.131,41$ & $20.771,59$ & $20.771,59$ & $431.458 .951,13$ \\
\hline 7 & 57.616 & $60.576,79$ & $-2.960,79$ & $2.960,79$ & $8.766 .277,42$ \\
\hline 8 & 54.249 & $61.022,17$ & $-6.773,17$ & $6.773,17$ & $45.875 .831,85$ \\
\hline 9 & 62.450 & $61.467,55$ & 982,45 & 982,45 & $965.208,00$ \\
\hline 10 & 54.170 & $61.912,93$ & $-7.742,93$ & $7.742,93$ & $59.952 .964,98$ \\
\hline & & 599.087 & $-0,20$ & $80.907,90$ & $1.127 .620 .043,96$ \\
\hline
\end{tabular}

$$
\begin{aligned}
& \text { MAD }=\sum\left|\frac{A-F}{n}\right|=\frac{80.907,90}{10}=8.090,79 \\
& \text { MSE }=\sum \frac{(A-F)^{2}}{n}=\frac{1.127 .620 .043,96}{10}=112.762 .004,40 \\
& \text { MFE }=\sum \frac{A-F}{n}=\frac{-0,20}{10}=-0,02
\end{aligned}
$$

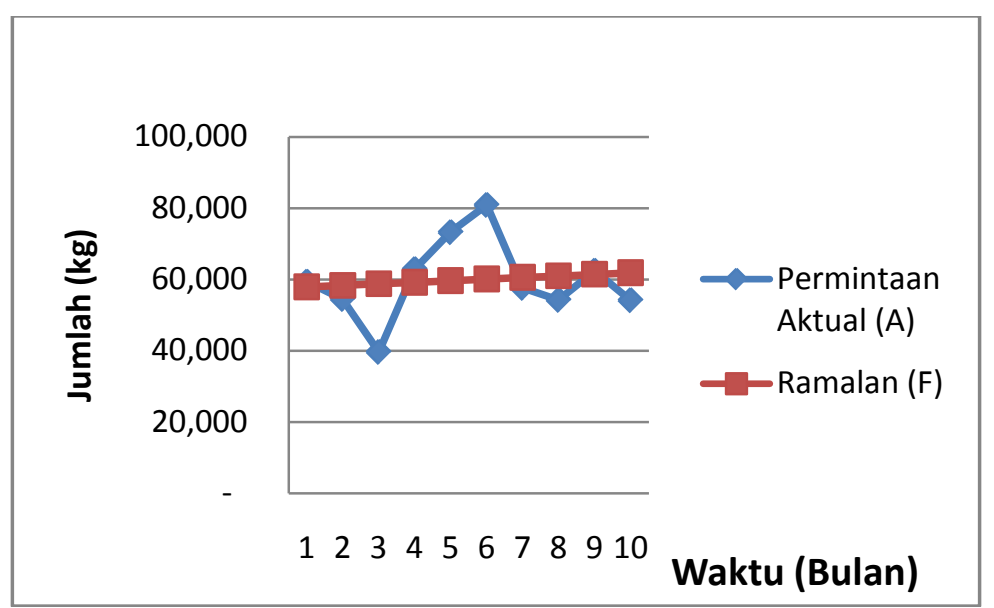

Gambar 6. Grafik Permintaan Aktual dan Peramalan Dengan Regresi Linier. 


\section{KESIMPULAN}

Berdasarkan dari kedua hasil perhitungan peramalan yang telah dilakukan, bisa dirangkum seperti yang tertera pada tabel 7 .

Tabel 7. Perbandingan Hasil Peramalan dan Ukuran Akurasi Metode Peramalan Exponential Smoothing dan Regresi Linier

\begin{tabular}{|l|l|}
\hline \multicolumn{1}{|c|}{ Exponential Smoothing } & \multicolumn{1}{c|}{ Regresi Linier } \\
\hline Manual: & Manual: \\
MAD $=9.663,00$ & MAD $=8.090,79$ \\
MSE $=137.428 .716,27$ & MSE $=112.762 .004,40$ \\
MFE $=53,55$ & MFE $=-0,02$ \\
Periode Berikut $=54.691$ & Periode Berikut $=62.358,51$ \\
\hline Software QM: & Software QM: \\
MAD $=13.374,1484$ & MAD $=8.812$ \\
MSE $=235.115 .376$ & MSE $=146.237 .392$ \\
Bias $=-549,8485$ & Bias $=0$ \\
Periode Berikut $=54.922,2266$ & Periode Berikut $=63.291,6$ \\
\hline
\end{tabular}

Nilai yang dihasilkan melalui bantuan perangkat lunak Software QM for Windows khususnya untuk Metode Regresi Linier diperoleh nilai yang lebih kecil, dimana untuk masing-masing itemnya adalah sebagai berikut: untuk MAD = 8.812, MSE = 146.237.392, Bias $=0$, untuk periode berikutnya diramalkan permintaannya sebesar 63.291,6 unit. Sedangkan jika menggunakan metode Exponential Smoothing diperoleh nilai-nilai sebagai berikut: untuk MAD $=13.374,1484$, MSE $=235.115 .376$, Bias $=-549,8485$, untuk periode berikutnya diramalkan jumlah permintaannya adalah sebesar 54.922,2266 unit. Sebagaimana diketahui bahwa nilai dari Metode Regresi Linier lebih kecil dibandingkan dengan metode Exponential Smoothing yang memiliki nilai ukuran akurasi kesalahan yang lebih kecil baik secara manual maupun dengan menggunakan software QM for Windows. Selebihnya terdapat beberapa hal yang perlu diketahui antara lain :

1. Peramalan pasti mengandung kesalahan artinya peramal hanya bisa mengurangi ketidakpastian yang akan terjadi tetapi tidak dapat menghilangkan ketidakpastian tersebut.

2. Peramalan seharusnya memberikan informasi tentang berapa ukuran kesalahan.

3. Peramalan jangka pendek lebih akurat bila dibandingkan dengan peramalan jangka panjang, karena dalam peramalan jangka pendek faktor-faktor yang mempengaruhi permintaan masih bersifat konstan.

Maka penulis menyarankan bahwa metode peramalan yang sebaiknya digunakan dalam merencanakan produksi tinta di PT. SKK yaitu metode Regresi Linier.

\section{DAFTAR PUSTAKA}

[1] Awwaliyyah, Nurdina, Mahmudah, “ Penerapan Metode Double Exponential Smoothing Dalam Meramalkan Jumlah Penderita Kusta Di Kabupaten Pasuruan. Fakultas Kesehatan Masyarakat, Universitas Airlangga. Jl. Mulyorejo Kampus C Unair, Surabaya 60115. 2014. Surabaya.

[2] Sahli, Muchamad, Susanti, Nanik, “ Penerapan Metode Exponential Smoothing Dalam Sistem Informasi Pengendalian Persediaan Bahan Baku (Studi Kasus Toko Tirta Harum)”, Jurnal SIMETRIS. Vol 3. No. 1 April 2013.ISSN:2252-4983. Universitas Muria Kudus. 2013. Kudus.

[3] QM for Windows. http://wps.prenhall.com/bp_weiss_software_1/1/358/91664.cw/. Diakses tanggal 12 Agustus 2013. 
[4] Wahyu, Anang, Abet, ” Penerapan Metode Double Exponential Smoothing Untuk Estimasi Hasil Penjualan “. Fakultas Teknologi Industri, Universitas Pembangunan Nasional “ Veteran “ Jawa Timur. 2012. Surabaya

[5] Pramita, Wahyu, Tanuwijaya, Haryanto, “ Penerapan Metode Exponential Smoothing Winter Dalam Sistem Informasi Pengendalian Persediaan Produk Dan Bahan Baku Sebuah Cafe“, Seminar Nasional Informatika. UPN : "Veteran” Yogyakarta, 22 Mei 2010.ISSN:1979-2328. 2010. Yogyakarta.

[6] Agung, S., Akbar, “ Penerapan Metode Single Moving Average Dan Exponential Smoothing Dalam Peramalan Permintaan Produk Meubel Jenis Coffee Table Pada Jaya Furniture Klaten “. Universitas Sebelas Maret Surakarta. 2009. Surakarta.

[7] Nasution, Arman, H., Prasetyawan, “ Perencanaan dan Pengendalian Produksi “, Graha Ilmu. 2008. Yogyakarta.

[8] Gazpers, Vincent, “ Production Planning and Inventory Control “, Gramedia Pustaka Utama. 2005. Jakarta.

[9] Nasution, Arman, H., “ Perencanaan dan Pengendalian Produksi “, Guna Widya. 2003. Jakarta.

[10] Subagyo, Pangestu, “ Forecasting Konsep dan Aplikasi “, BPFE. 2001. Jakarta. 